politics and sociology. This is not to suggest that there can be a 'pure' psychology. Psychologists realize, like sociologists, that 'man is a social animal', but the biological aspects of social problems become increasingly important with advance in the biological sciences.

For these reasons the organization of psychology within the degree-structures of some of the universities of tra. ditional pattern still offers the best path of progress. Where psychology has membership of the three faculties of arts, science and social sciences, and has appropriate joint honours options in each, all the essential links of the discipline, in conformity with the principle of the 'unity of knowledge', will be safeguarded.

It is suggested finally that the implementation of the 1946 Clapham Report, though perhaps more cautious and sceptical than would meet the changed situation of to-day, put the stress of any expansion in the right place-in the proper staffing of disciplines which are faced with especially time-consuming problems of applied research, in a period of explosive interest in the social sciences among sixth formers and a Robbins expansion which will probably, in these subjects, have been underestimated.

\title{
PHYSICAL APPROACHES TO SOME BOTANICAL FROBLEMS
}

$I^{\mathrm{N}}$ $\mathrm{N}$ his presidential address to Section K (Botany), Prof. R. D. Preston considers the fine structure of plant cell walls as an example of the powers of physical approaches to some botanical problems. In common with all other metabolic products, the polysaccharides of plant cell walls are the consequence of a chain of enzyme-controlled reactions specified by the appropriate DNA, and he takes the opportunity both of examining the bearing of wall structure on cell growth and shape and of tracing back some steps in wall biosynthesis as they appear to be demanded by wall structure, as part of the chain of events leading from DNA to the expression of plant form.

The walls of almost all plant cells are based on a common plan involving, namely, an array of long thin rods (microfibrils) some $100 \AA-300 \AA$ in diameter and of indefinite length, embedded in a matrix. The rods are in part crystalline; so far as is known, they consist in all higher piants of cellulose, a $\beta$-1,4-linked glucan, though in some lower plants, all seaweeds, they contain instead a $\beta-1,3$ linked xylan with distinctly different physical structure and properties which are discussed. Whether glucan or xylan, the rods are strong in longitudinal tension; laterally they are bonded together through other polysaccharides in the matrix, giving a structure which is less resistant to tensions applied at right angles to microfibril direction. The (in this sense) anomalous condition of some other seaweeds, in which the crystalline component is $\beta-1,4-$ linked mannan not organized into visible microfibrils, is not necessarily a departure from the common plan.

The mechanical properties of an array of parallel microfibrils are, therefore, anisotropic; in particular, such an array, when subjected to stress, creeps much faster when the direction of stress lies at right angles to the microfibril direction than it does when stressed parallel to this.
Since plant cells grow, at least in large part, through a yielding of the wall due to stresses invoked by turgor pressure, it follows that the rate of cell growth, and the direction of yielding of the wall and, therefore, the ultimate shape of the cell-and indirectly of the plantshould be a function of wall structure. Examples are given to show that, in those instances examined, these expectations are fulfilled. There is no doubt but that control of cell growth and cell shape is achieved in large part through wall structure. The control mechanism is, therefore, in principle on call from the first moment of deposition of the wall.

The details of wall architecture vary widely over the plant kingdom, but it is striking how many plants possess lamellated walls in which the constituent microfibrils of each lamella lie rather beautifully parallel to each other and in how many of these a single cell wall shows two or three different microfibril directions and no other. Detailed physical examination of these walls allows the main features of the microfibril-synthesizing and -orienting mechanism to be defined in principle. Each microfibril must be produced by end-synthesis through an enzyme complex which may be envisaged as particles larger in diameter than the microfibrils and attached to at least one end of each. These particles must be ordered at the surface of the cytoplasm, probably in cubic close packing. Such arrays of particles have been seen in the electron micrographs of formalin-fixed material, but since then, and much more convincingly, in freeze-splintered material in Frey-Wyssling's School at Zurich. It remains to be seen whether these can be identified with the particles shown by Hassid to build the glucose moiety of guanidine diphosphate glucose into cellulose, and to assess the significance of the microtubules now known in many cells to lie near to the wall-synthesizing cell surface.

\section{THE CHANGING AIMS OF FORESTRY}

$\mathrm{M}$ R. C. W. SCOTT has chosen as the subject of his chairman's address to Sub-Section $\mathbf{K}^{*}$ (Forestry) "The Changing Aims of Forestry". The aims of forestry are to supply what is wanted from the forests, and as the demands change, so also must the aims. The trend of present demand is for woods of different type and size from those required in other centuries - or even recent decades. Growing wood is the primary function of forestry, though forests have other important functions.

Great changes are in hand to meet the swift rise of human populations and standards of living, and the rising demands for wood on a great scale in the form of plywood, man-made boards, and pulp and paper. Other causes of change in forestry are new machines and the cost and limited supplies of labour. Work and life in or near forests are usually less attractive to labour than on farms or in towns.

The demand for wood in Europe. In 1964 the United Nations published a valuable study in detail of the demand for wood in Europe, excluding the U.S.S.R., during the period $1900-2000$, and specially the period 1950-75. During 1900-50 the growth of demand was modest; but during 1950-75 this demand is likely to double, with larger imports. By the year 2000 the gap between Europe's annual growth of wood and her annual use may be $100-160$ million $\mathrm{m}^{3}$, or some $3,500-5,000$ 